\title{
INNOVATION AND RESEARCH AND DEVELOPMENT ACTIVITIES IN PODKARPACKIE VOIVODESHIP IN THE YEARS 2005-2016
}

\author{
Sławomir Stec, Eng $\mathrm{PhD}^{1}$; Monika Szeląg, $\mathrm{Msc}^{2}$
}

Technology Transfer Center, Rzeszów University of Technology

\begin{abstract}
The article describes the activities related to running innovative activities and presents the dynamics of changes in expenditure on research and development as well as innovation in Podkarpackie Voivodeship in the years 2005-2016. Following article consist short characteristic of activities connected with innovation issue. It was found that the number of entities conducting R\&D activities increased four times, and thus the employment of people dealing with research and development would grow as well. Similarly, the expenditure of these entities on the implementation of innovations increased, which, however, depended to some extent on the availability of EU funds. Thereby, in the period of reduced access to EU programs supporting the conduct of R\&D activity, the expenditure of entities on these activities also slightly decreased.
\end{abstract}

Keywords: entrepreneurship, innovation, innovative company, innovation management, innovation processes, service innovation, technological innovation JEL codes: O31, O32, O34

\section{INTRODUCTION}

The turn of the 20th and 21 st centuries was characterized by intensive development of innovation implementations. In particular, this process intensified in the European Union countries, where appropriate standards were developed and the market was unified.

Innovations themselves are a very important factor stimulating the development of the company. The whole environment is subject to constant changes, and competition constantly improves an innovation management process; that is why it is so important to continuingly implement novelties causing the entity to grow rapidly, which results in its significant com- petitive advantage. Therefore, it can be stated that innovation is the source of entrepreneurship.

However, currently economic and development processes are forming in more and more specific systems of connections in which the creation of innovative or technologically advanced solutions requires the cooperation of enterprises with the environment, including public administration, business environment institutions and science and research units. Currently, intensive shifting of structures of developed economies towards industries and knowledge-based services is observed. The construction of a modern, knowledge-based economy requires long-term investments and system support for enterprises, universities, research and development units and business environ-

${ }^{1}$ Corresponding author: al. Powstańców Warszawy 12, Rzeszów, s.stec@prz.edu.pl, +48178651689

${ }^{2}$ Corresponding author: al. Powstańców Warszawy 12, Rzeszów, mszelag@prz.edu.pl 
ment institutions. An important element of this arrangement is to stimulate cooperation and implement solutions that will reduce the problem of insufficient mechanisms for binding scientific research with the ability of the company to absorb new technologies, products or innovative solutions (Pastusiak, 2009).

The above-mentioned issues relate to spending some outlays on research and development (R\&D) and innovative activities. The analysis of funds invested for $R \& D$ allows for conducting research in the field of innovation in the economy on a regional or national scale, and in comparison with data on reported inventions, patents received, or sales of new and upgraded products and their export, it allows to determine the level of effectiveness of expenditures.

The main problem is to show dynamic changes on research-development expenditures and innovation in Podkarpackie Voivoidship in years 2005-2016.

The basic purpose of following article is attempt to answer if there is any growth of expenditures on the research-development and innovation activity and the same if there are any changes in the subject structure and persons running R\&D activity.

Research and development and innovation in the light of theoretical considerations

In the continuous progress of globalization, the competitiveness of enterprises on the microeconomic scale depends on the degree of technological advancement and competitiveness of the entire country. Introducing new or significantly improved applications, products or processes onto the market is associated with the concept of innovation, which was introduced for the first time to economics by Schumpeter. He described innovation as (Schumpeter, 1960):

- introducing a new product or giving new features to an already existing product;

- introduction of a new production method or its improvement;

- opening a new market;

- acquiring and applying a new source of raw materials or semi-finished products;

- introduction of a new organizational structure for a given industry;

- applying a new way of selling or purchasing. Nowadays, this definition has expanded considerably and has gone far beyond the realm of technology.
Innovation is thought to take place when economically viable exploitation of new ideas takes place (Porter, 1990). Innovations are treated here as a series of technical and organizational changes, including on the one hand simple modifications of existing products, processes and practices (which may be new for the enterprise but not necessarily for the industry) to fundamentally new products and processes on the other (which are new for the industry as well as for the subject). Implementation of innovation involves a whole range of scientific, technological, organizational, financial and commercial activities.

The best-known definition, used almost anywhere in the world is the one presented in Oslo Manual, where innovation means the implementation of a new or significantly improved product (including goods or services), a new or significantly improved process, a new marketing method or a new organization method in the field of business practices, workplace organization or relations with the external environment. For the needs of scientific and technical policy, as well as for maintaining comparability over time with the results of previous statistical surveys of innovations, in many cases the so-called narrower definition is used, where innovation means only 'technical' innovations, i.e. new or significantly improved products and processes. Products (goods and services), processes and methods (technical, organizational and marketing) are innovations if they are new or significantly improved at least from the point of view of the enterprise implementing them (OECD, 2005).

This is very similar to the Oslo Manual hand book - an innovation concept is defined in the law bill dated 30 May 2008 about different forms of innovation support (where meaning of innovation is understand as activity of describing new technology it means technology as the industrial property or research - development service which enables to produce new or high upgraded goods, processes or services and don't exist longer than 5 years) and start from it production of new or highly upgraded goods, processes and services and as technology investment it means to buy new technology, elaborate own technology, and introduce and start producing new or highly upgraded goods and services. 
The Polish authors describes innovation as ability and motivation business entitles to constant research and use in practice the scores of science researches, new concepts, ideas and inventions. This is the meaning of Kot (2007).

Very narrow meaning of innovation presents Pomykalski, who is showing us that innovation is process gathered all activities connected with creation of ideas, creation of inventions then introducing itself as new product or process (Pomykalski, 2001).

Another point of view presents Bogdarenko who thinks that innovation term means ability for making and introducing innovations which can be used in the different fields of economic - society life (Bogdarenko, 2006)

Above definitions also Polish as foreign authors and institutions and almost the same in meaning. But there is no explicitness to this term and this cause that is very difficult to use objective criteria and classification of innovation levels.

Despite of different interpretation of this term is possible to show four different basics of innovations:

- marketing, which is characterized by the implementation of a new marketing concept or strategy that differs significantly from the marketing methods used so far in the enterprise;

- organizational, i.e. the implementation of a new organizational method in the principles of operation adopted by the entity, in the organization of the workplace or in relations with the environment, which has not been used so far in the enterprise;

- process-based, indicating the implementation of new or significant improvement of the existing methods of production, distribution and support of activities in the field of products and services;

- product-based, which means the launch of a product or service that is new or significantly improved in terms of its characteristics or applications (OECD, 2005).

Process and product innovations belong to technological innovations. In turn, marketing and organizational innovations are classified as non-technological innovations (Mazur-Wierzbicka, 2015).
In order to develop new solutions or to create a new product, an innovator, i.e. a person or entity involved in implementing innovations, should conduct innovative activity through all scientific, technical, organizational, financial and commercial activities. Some of these activities are innovative in nature, while others are not new, but are necessary to implement innovations. Innovative activity includes also research and development (R\&D), which is not directly related to the creation of a specific innovation (GUS, n.d.). An entity that is called an innovative one should be characterized by conducting activities and investing financial resources in the scope of research and development works. These activities should lead to the development of the enterprise.

The aforementioned R\&D activity of a given entity consists of creative work, carried out in a methodical manner, undertaken to increase knowledge resources and to create new applications for existing knowledge that ultimately leads to the introduction of 'a new or significantly improved product, service or process to the economy, including the implementation of a new marketing or organizational method that redefines the way the company works or relations with its surroundings' (Buczkowski, Szpor and Śniegocki, 2012).

R\&D activities include several types of research:

- basic research, which includes experimental or theoretical work, undertaken primarily to acquire new knowledge about the basics of phenomena and observable facts, without focusing on practical applications or use;

- industrial research (applied), that is research aimed at acquiring new knowledge and skills to develop new products, processes and services or to introduce significant improvements to existing products, processes or services;

- development work, i.e. acquisition, merger, shaping and utilization of currently available knowledge and skills in the field of science, technology and business and other knowledge and skills for production planning as well as the creation and design of new, changed or improved products, processes or services.

The following should be mentioned among the entities conducting research and development activities: 
- scientific and research and development units, i.e. units whose main activity is to conduct research and development (scientific institutions of the Polish Academy of Sciences, state and private research and development units);

- science service units (scientific libraries, scientific archives, scientific associations and other science service units);

- development units, i.e. business entities, primarily industrial enterprises, having their own research and development facilities (laboratories, construction offices, technical development centres, etc.), conducting research and development activities mainly on the nature of development works, in addition to their core operations;

- higher education units (US Rzeszów, 2018).

\section{MATERIALS AND METHODS}

The research and analyses presented in the work are based on the theory of economics. The spatial scope of the research covers the area of Podkarpackie Voivodeship, and the time scope applies to the years 2005-2016. The analyses were based on the literature of the subject, analysis of current research and mass statistics data provided by the Central Statistical Office. Methods of processing and interpretation of optional knowledge were used using a descriptive method, a method of tabular and descriptive analysis and graphic presentation, as well as subject literature studies.

Detailed analyse takes under consideration numerous data gathered all business entitles running R\&D activity from Podkarpackie Voivodeship with showing factories and universities.
To the analyse of these business entitles working as R\&D factories used the factors of workers as number of persons hired in that factories and also the time of working. In case of research-development expenditures took appointment of type of expenses (R\&D activity, know-how, software, assets investment, training of workers and marketing).

\section{RESULTS AND DISCUSSION}

In the analysed period, the number of entities conducting business activity increased substantially. Since 2005, the number of units involved in R\&D in Podkarpackie Voivodship has increased seven times. At the same time, it should be noted that this trend is constantly maintained and the largest increase in the number of entities was recorded in 2015, where research and development activities were declared by twice as many entities as in the previous year and six times more than in 2005 (Table 1). This probably results from the fact that there is more and more access to finance for conducting the discussed activity. These are mainly EU funds from such operational programs as: Knowledge Education Development, Innovative Development and Regional Operational Programs.

In the context of the analysis of the sector of entities conducting R\&D activity, it should be stated that the number of business entities (industry and services) increased significantly from 48 in 2005 to 199 in 2016, which is a fourfold increase. By contrast, the number of higher education institutions that conduct such activities increased from 3 to 8 over the last decade and since 2013 has remained at the same level. Rzeszów University of Technology and the Univer-

Table 1. Entities conducting research and development activities in the years 2005-2016

\begin{tabular}{|l|c|c|c|c|c|c|c|c|}
\hline Specification & 2005 & 2007 & 2009 & 2011 & 2013 & 2014 & 2015 & 2016 \\
\hline $\begin{array}{l}\text { Entities performing R\&D } \\
\text { (in total) }\end{array}$ & 53 & 56 & 53 & 83 & 137 & 158 & 314 & 346 \\
\hline $\begin{array}{l}\text { Business entities conducting } \\
\text { R\&D activity }\end{array}$ & 48 & 51 & 46 & 68 & 120 & 136 & 172 & 199 \\
\hline $\begin{array}{l}\text { Higher education institutions } \\
\text { conducting R\&D activity }\end{array}$ & 3 & 3 & 5 & 7 & 8 & 8 & 8 & 8 \\
\hline
\end{tabular}

Source: own study based on GUS data from 2005-2016. 
Proceedings of the 2018 International Scientific Conference 'Economic Sciences for Agribusiness and Rural Economy' No 1, Warsaw, 7-8 June 2018, pp. 243-249

sity of Rzeszów were joined by the State Higher Vocational Schools and non-public schools.

Adequate to the growing number of entities conducting research and development activity, the number of people working in R\&D sector has also increased. In the analysed period, the number of employed persons increased almost threefold from 3,129 to 8,291 persons (Table 2). Even greater increase was recorded in the case of full-time employees (EPC), which amounted to nearly $400 \%$. In turn, when conducting the analysis of the employed in particular sectors, it should be stated that there were more jobs in $\mathrm{R} \& \mathrm{D}$ in business entities (fourfold increase) than in higher education (threefold increase). This is due to the growing number of business entities implementing innovations.
Characterizing expenditures on innovative activity, an analysis was made of total expenditure and expenditure on direct $\mathrm{R} \& \mathrm{D}$, purchase of knowledge from external sources, purchase of software, investments in the form of buildings and plots, land, machinery and technical equipment with tools and means of transport, personnel training or trainings relating to innovative activities, as well as marketing of new or significantly improved products.

In the analysed period, the overall expenditure on innovative activity gradually increased. Over the last decade, these expenditures increased more than twofold, from over PLN 670,000 to over 1.47 million (Table 3). The situation looks similarly in the expenditure on $\mathrm{R} \& \mathrm{D}$, however, with the exception of 2015 , when expenditures fell by $32 \%$ compared

Table 2. Employees in research and development in the years 2005-2016

\begin{tabular}{|l|c|c|c|c|c|c|c|c|}
\hline Specification & 2005 & 2007 & 2009 & 2011 & 2013 & 2014 & 2015 & 2016 \\
\hline Working in R\&D (total)* & 1474.2 & 1461.2 & 1604.7 & 2851.3 & 4329.8 & 5925.7 & 5441.3 & 5708.4 \\
\hline Working in R\&D (total)* & 3129 & 3115 & 3549 & 6622 & 7339 & 8749 & 7935 & 8291 \\
\hline $\begin{array}{l}\text { Persons employed in } \\
\text { R\&D in business entities }\end{array}$ & 977.9 & 936.3 & 1028.9 & 2209.5 & 3486.1 & 4941.1 & 3810.8 & 4126.3 \\
\hline $\begin{array}{l}\text { Persons employed in } \\
\text { R\&D in in higher education } \\
\text { institutions }\end{array}$ & 490.3 & 518.1 & 573.8 & 641.8 & 756.5 & 871.9 & 1486.3 & 1501.2 \\
\hline
\end{tabular}

* so-called full-time equivalent.

Source: own study based on GUS data from 2005-2016.

Table 3. Expenditure on innovation by type of innovative activity in 2005-2016

\begin{tabular}{|l|c|c|c|c|c|c|c|c|c|}
\hline Expenditures & 2005 & 2007 & 2009 & 2011 & 2013 & 2014 & 2015 & 2016 \\
\hline \multicolumn{7}{|c|}{ in PLN } \\
\hline Total & 670984 & 905066 & 949168 & 1089532 & 1069119 & 1443821 & 1415467 & $\begin{array}{c}1471 \\
647\end{array}$ \\
\hline R\&D activity & 99403 & 117494 & 152792 & 259399 & 439587 & 551969 & 379000 & 708705 \\
\hline Purchase of knowledge & 11185 & 43447 & 26152 & 7622 & 8022 & 4051 & 1783 & 6317 \\
\hline Purchase of software & 11025 & 17864 & 28266 & 16734 & 34120 & 14392 & 11316 & 11566 \\
\hline Investments in fixed assets & 425245 & 475432 & 458044 & 634683 & 364210 & 621559 & 750327 & 606207 \\
\hline Staff training & 1445 & nd & nd & 3915 & 2605 & 4596 & 3867 & 6798 \\
\hline Marketing & nd & nd & nd & 38860 & 10379 & 30085 & 13866 & 12603 \\
\hline
\end{tabular}


to the previous year. It is connected with the transitional period of access to EU funds for such activity. The same applies to the purchase of knowledge and software, or staff training, for which the units acquire external funds. In the case of investments in fixed assets, it should be noted that in the years 2005-2009, expenditures for this purpose remained at a similar level. In the following years, expenses increased by over $50 \%$. Only in 2013 there was a decrease in expenses, which was also caused by reduced access to EU programs.

In the financing structure of innovative activity over the period under review, only little changed, as expenditures were dominated by own funds $(80-89 \%)$ (Fig. 1). There is a noticeable decline in the financing of the said activity through loans granted to individual entities.

In the analysed period, expenditures on research and development activities grew significantly. In 2005 in Podkarpackie Voivodeship, PLN 111.6 million was spent on R\&D, and in 2014 it was already nearly 931 million. However, from 2015, the amount of outlays began to decline slowly to reach PLN 762.9 million in 2016. This can also be explained by the end of the previous period of EU budgeting and the launch of the budget perspective 2014-2020 (Fig. 2).

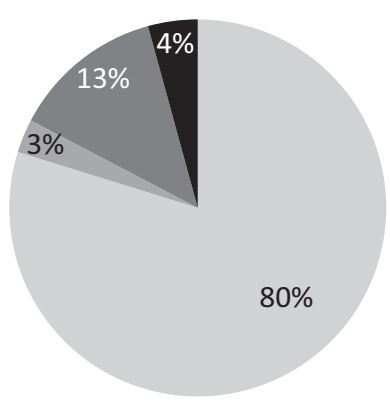

2005 r.

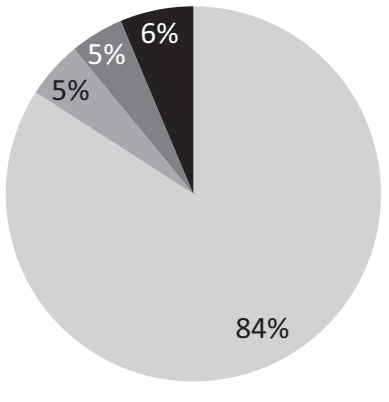

$2010 \mathrm{r}$.

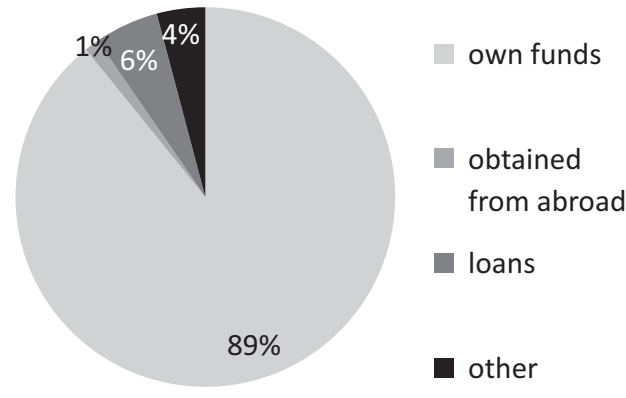

2016 r.

Figure 1. Structure of expenditures on innovative activity by sources of financing in 2010-2016 Source: own study based on GUS data from 2005-2016.

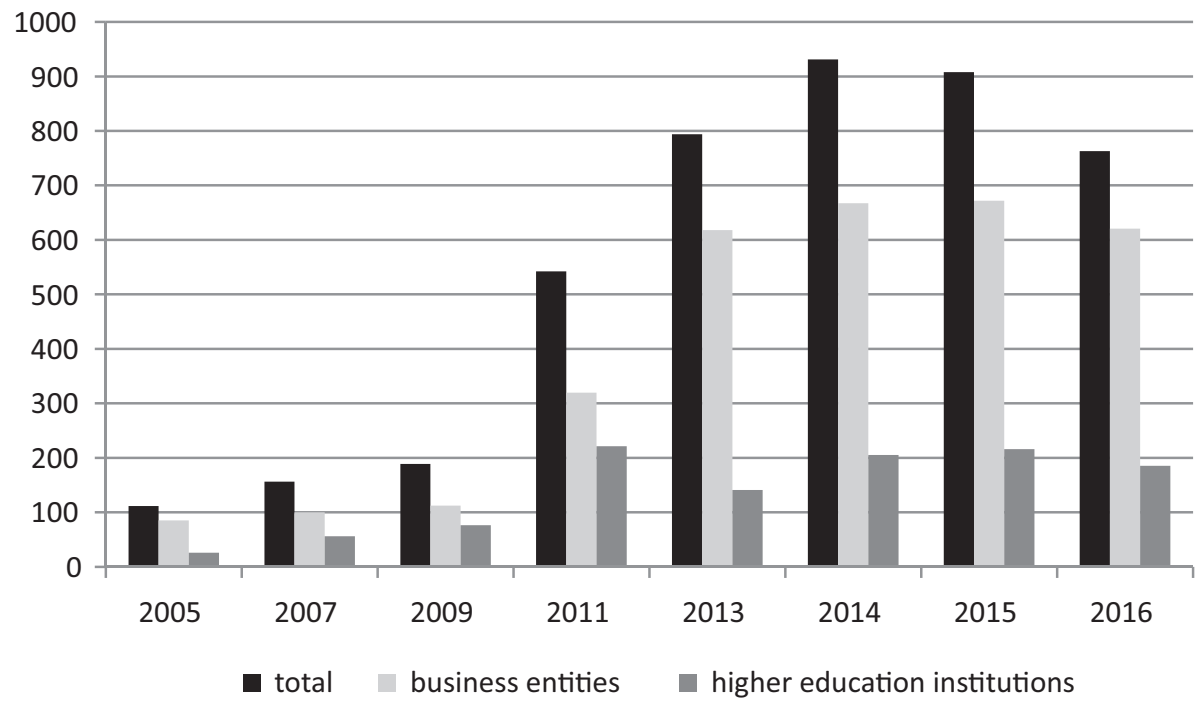

Figure 2. Expenditures on research and development activities by financing sectors in the years 2005-2016 Source: own study based on GUS data from 2005-2016. 
It should be noted that significant increase in expenditure on research and development took place in business entities while in higher education institutions, after increase in the years 2005-2011, there was a stabilization of expenditure at a similar level of about PLN 200 million.

\section{CONCLUSIONS}

Analysed period of time shows that R\&D field in Podkarpackie Voivoidship had considerable changes. Above data shows increased interesting in innovation and research - development activity by the different business entitles. In particular, manufacturing and service enterprises increased their activity in this area, thus trying to strengthen their position in a very competitive market. In the years 2005-2016, the number of entities increased more than four times, and as a result, the employment of research and development personnel also increased.

However, there is a noticeable dependence in expenditure on innovative activity on the availability of EU funds. Thereby, in the period of reduced access to EU programs supporting the conduct of $\mathrm{R} \& \mathrm{D}$, the expenditure of entities on these activities also decreased.

In the next few years, a further increase in the number of involved entities, people employed in innovative activities and, above all, increase in research and development expenditures is forecasted. It is to be supported, among others, by so-called second act on innovation, adopted in 2017, which allows the entrepreneur to deduct from the tax base $100 \%$ of innovation expenditures. High impact was introduction of obligatory financing at $2 \%$ funds for Technology Transfer Centres (Act of 30 April 2010 on the principles of financing science).

\section{REFERENCES}

1. Bogdarenko, J. (2006). Innowacyjność przedsiębiorstw [Enterprises innovation]. Wydawnictwo Uniwersytetu Mikołaja Kopernika, Toruń.
2. Bukowski, M., Szpor, A., Śniegocki, A. (2012). Potencjał i bariery polskiej innowacyjności. [Potential and barriers of Polish innovation]. Instytut Badań Strukturalnych, Warszawa.

3. GUS (n.d.). Działalność innowacyjna [Innovative activity]. In: Słownik pojęć [Dictionary of terms]. Retrieved form: http://stat.gov.pl/metainformacje/slownikpojec/pojecia-stosowane-w-statystyce-publicznej/ 759,pojecie.html [Accessed 23.05.2018].

4. Kot, J. (2007). Konkurencyjność i innowacyjność w rozwoju regionalnym [Competitiveness and innovation in regional development]. In: Analiza strukturalna gospodarki regionu świętokrzyskiego i jej wykorzystanie pod kątem podnoszenia konkurencyjności i innowacyjności region [Structural analysis of the economy of the Świętokrzyskie region and its use in terms of increasing the region's competitiveness and innovation]. Wydawnictwo Akademii Świętokrzyskiej, Kielce, p. 11.

5. Mazur-Wierzbicka, E. (2015). Działalność innowacyjna przedsiębiorstw w Polsce [Innovative activity of enterprises in Poland]. Zeszyty Naukowe Małopolskiej Wyższej Szkoły Ekonomicznej w Tarnowie, 1 (26), pp. 97-109.

6. OECD (2005). Oslo Manual. Guidelines for Collecting and Interpreting Innovation Data. 3rd ed. OECD/ /Eurostat, Paris.

7. Pastusiak, R. (2009). Rola innowacyjności w budowaniu pozycji konkurencyjnej przedsiębiorstwa [The role of innovation in building the competitive position of enterprises]. Przegląd Organizacji, 5, pp. 17-18.

8. Pomykalski, A. (2001). Innowacje [Innovations]. Wydawnictwo Politechniki Łódzkiej, Łódź.

9. Porter, M.E. (1990). The Competitive Advantage of Nations. The Macmillan Press, London.

10. Schumpeter, J. (1960). Teoria rozwoju gospodarczego [Theory of economic development]. PWN, Warszawa.

11. Urząd Statystyczny Rzeszów (2018). Rocznik Statystyczny Województwa Podkarpackiego 2017 [Statistical Yearbook of the Podkarpackie Voivodeship]. Rzeszów.

12. Ustawa $z$ dnia 30 kwietnia 2010 r. o zasadach finansowania nauki [Act of 30 April 2010 on the principles of financing science]. Journal of Laws from 2010 No 96, item 615 . 